\title{
Quercetin inhibits human breast cancer cell proliferation and induces apoptosis via Bcl-2 and Bax regulation
}

\author{
JIAN DUO $^{1}$, GUO-GUANG YING ${ }^{2}$, GUO-WEN WANG ${ }^{1}$ and LI ZHANG $^{3}$ \\ ${ }^{1}$ Department of Bone and Soft Tissue Tumors, Tianjin Medical University Cancer Institute and Hospital, \\ Key Laboratory of Cancer Prevention and Therapy, Tianjin; Key Laboratory of Breast Cancer Prevention and Therapy, \\ Tianjin Medical University, Ministry of Education; ${ }^{2}$ Central Laboratory of Oncology Department, \\ Tianjin Medical University Cancer Institute and Hospital, Tianjin; ${ }^{3}$ Department of Gynecologic Cancer, \\ Tianjin Medical University Cancer Institute and Hospital, Key Laboratory of Cancer Prevention and Therapy, \\ Tianjin; Key Laboratory of Breast Cancer Prevention and Therapy, Tianjin Medical University, \\ Ministry of Education, Tianjin, P.R. China
}

Received November 21, 2011; Accepted February 14, 2012

DOI: $10.3892 / \mathrm{mmr} .2012 .845$

\begin{abstract}
Breast cancer is a disease in which cancer cells form in the tissues of the breast. The present study aimed to explore the effect of the flavonoid compound quercetin on the growth and apoptosis of human breast cancer cells. Varying concentrations $(12.5,25,50,100,200 \mu \mathrm{M})$ of quercetin were applied to cultured MCF-7 human breast cancer cells for defined lengths of time. At 50 to $200 \mu \mathrm{M}$ doses, quercetin significantly inhibited the proliferation of MCF-7 cells assessed by MTT colorimetry, in both dose- and time-dependent manners $(\mathrm{P}<0.05)$. The compound also increased apoptosis after $48 \mathrm{~h}$ of exposure $(\mathrm{P}<0.05)$. Furthermore, following quercetin treatment Bcl-2 expression decreased significantly while Bax expression increased significantly $(\mathrm{P}<0.05)$. In brief, quercetin inhibits cell growth and induces apoptosis in MCF-7 human breast cancer cells. The mechanisms behind these effects may stem from the downregulation of Bcl-2 protein expression and upregulation of Bax expression.
\end{abstract}

\section{Introduction}

Breast cancer is one of the most common malignancies in humans, accounting for $7-10 \%$ of all malignant tumors; its incidence increases at an annual rate of 1-2\% (1). According to World Health Organization Statistics, about 1.3 million women are diagnosed with breast cancer each year. In North America, Europe, and other developed countries, the incidence of breast cancer ranks first among all malignant tumors in women, and

Correspondence to: Dr Li Zhang, Department of Gynecologic Cancer, Tianjin Medical University Cancer Institute and Hospital, Huanhuxi Road, Hexi, Tianjin 300060, P.R. China

E-mail: zhangli2334@126.com

Key words: quercetin, human breast cancer cells, proliferation, apoptosis, protein expression its mortality ranks second only to lung cancer among deaths caused by malignant tumors in women $(2,3)$. In recent years, the incidence of female breast cancer in China has risen. In fact, this incidence increased from 19.9/100,000 in 2000 to $24.8 / 100,000$ in 2005, making breast cancer the most common malignancy in Chinese women. Furthermore, the number of deaths from breast cancer in women increased from 34,927 to 48,764 during the same period, with the mortality rate increasing from 5.5/100,000 to 6.7/100,000 (4).

Current treatment of breast cancer follows an integrated therapeutic model, which includes surgery, radiation therapy, chemotherapy, endocrine therapy, and biological therapy; this approach has made breast cancer one of the most successfully treatable solid tumors (5). Chemotherapy is irreplaceable in this treatment plan. In the last 30 years, more than 100 clinical trials from many countries have confirmed that postoperative adjuvant chemotherapy for breast cancer kills systematic submicrometastases, thereby reducing postoperative recurrence and mortality rates of breast cancer (6). Although current chemotherapeutics are able to inhibit or kill tumors, there remain issues of toxicity and severe side effects, restricting the clinical application of these drugs in antitumor treatment. Thus, the exploration and development of new antitumor chemotherapeutics is critical to improving the integrated treatment plan.

One potential antitumor compound is quercetin. Quercetin and its derivatives, which are easily extracted, isolated, and detected, are widely distributed in the natural world; quercetin is a flavonoid compound found in many fruits, vegetables and herbs. This compound is biologically active, able to expand coronary arteries, reduce capillary permeability and fragility, and prevent platelet aggregation, as well as possessing other antioxidant, anti-virus, anti-allergic, analgesic, and other pharmacological effects (7). Recent studies (8-10) have found that quercetin is also able to prevent and treat tumors, by not only inhibiting many carcinogens and tumor promoters, but also preventing growth of tumor cells. To determine the ability of quercetin to treat breast cancer, we investigated the effects 


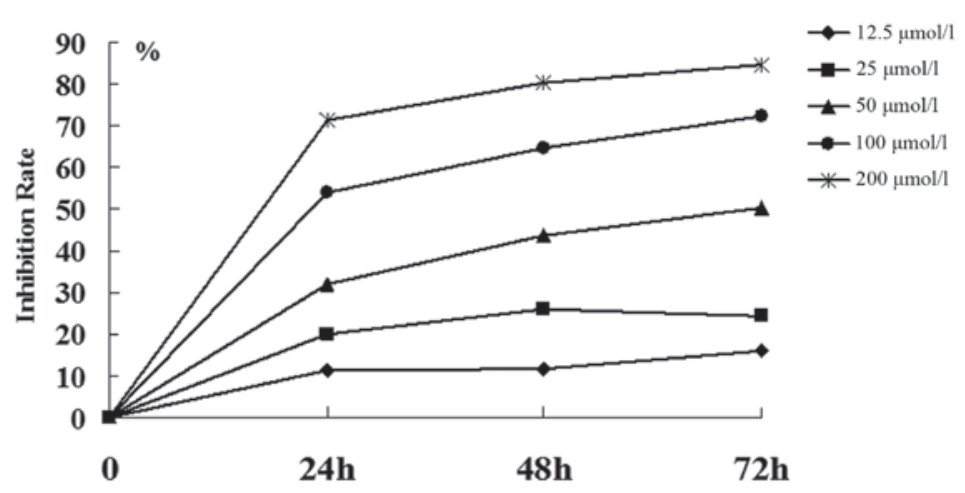

Figure 1. Relationship between time and inhibition rates of MCF-7 cells after treatment with different concentrations of quercetin.

of quercetin on in vitro proliferation and apoptosis of human breast cancer MCF-7 cells using MTT colorimetry and flow cytometry. Furthermore, we assessed the induction of apoptosis in MCF-7 cells following quercetin treatment by observing changes in apoptosis-related $\mathrm{Bcl}-2$ and Bax protein expression.

\section{Materials and methods}

Materials and reagents. Human breast cancer MCF-7 cells were supplied by the School of Life Sciences, Xiamen University. Quercetin (Sigma, USA; lot no. 100081-200406) was suspended in dimethyl sulfoxide (DMSO) and stored at $-20^{\circ} \mathrm{C}$. Prior to use, quercetin was diluted with Dulbecco's modified Eagle's medium (DMEM) to a final concentration of $0.8 \%$. Fetal bovine serum (FBS), DMEM, DMSO, trypsin, and MTT were purchased from Beijing Zhongshan Golden Bridge Biotechnology Co., Ltd. Mouse anti-human Bcl-2 and Bax monoclonal antibodies and the SP immunohistochemistry kit were purchased from Wuhan Boster Bio-Engineering Limited Company. The flow cytometer was purchased from US Gene Company.

Experimental methods. MCF-7 cell growth was assessed using the MTT method. MCF-7 cells were cultured in 10\% DMEM (containing $10 \% \mathrm{FBS}$ and $100 \mathrm{U} / \mathrm{ml}$ streptomycin) at $37^{\circ} \mathrm{C}$ in $5 \% \mathrm{CO}_{2}$, under saturated humidity conditions. Medium was replaced every two days. MCF-7 cells were harvested during logarithmic growth phase, digested with $2.5 \mathrm{~g} / 1$ trypsin, and resuspended to a cell concentration of $1 \times 10^{5} / \mathrm{ml}$. Two hundred microliters of suspension was transferred to each well of a 96-well culture plate and cultured for $24 \mathrm{~h}$. Quercetin was then added to a subset of wells at concentrations of 12.5, 25, 50, 100 and $200 \mu \mathrm{M}$. Control wells contained only MCF-7 cells without quercetin, and blank wells contained only culture medium. Three replicates were established for each group, and three plates were added at a time. After 24, 48 and $72 \mathrm{~h}$ in culture, $20 \mu \mathrm{l}$ MTT $(5 \mathrm{mg} / \mathrm{ml})$ was added to each well, and plates were incubated at $37^{\circ} \mathrm{C}$ for $4 \mathrm{~h}$. Supernatants were extracted and discarded, and $200 \mu \mathrm{l}$ DMSO were added to each well with shaking to completely dissolve the blue-purple precipitate from MTT. A microplate reader was used to test the absorbance (A) of each well at $490 \mathrm{~nm}$, and average values were obtained. Time (x) and A value (y) were used to create a growth curve and determine inhibition rates of quercetin on MCF-7 cells at different time points and concentrations inhibition rate (IR) $=$
[(A490 in control group - A490 in experimental group)/A490 in control group] x $100 \%$ \}.

Cell cycle detection by flow cytometry. Following incubation with quercetin, cells were digested with trypsin and dispersed. Samples were centrifuged at $1500 \mathrm{rpm}$ for $5 \mathrm{~min}$, supernatants were discarded, and $200 \mu \mathrm{l} 1 \mathrm{X}$ buffer was added. Annexin V (4 $\mu \mathrm{l})$ and propidium iodide (PI) $(5 \mu \mathrm{l})$ were added to each sample, which was brought to a final volume of $250 \mu 1$ with $1 \mathrm{X}$ buffer before placing in an ice bath. Flow cytometry was used to determine the cell cycle and apoptosis rate. MCF-7 cells cultured for $72 \mathrm{~h}$ without quercetin were used as the negative control.

Bcl-2 and Bax detection by immunohistochemistry. Four bottles of MCF-7 cells in logarithmic growth phase ( $1 \times 10^{5}$ cells/bottle) were randomized to the control and experimental groups, 2 bottles/group. Those in the experimental group were cultured with medium containing $200 \mu \mathrm{M}$ quercetin; those in the control group were cultured with conventional methods. After 48 h, one bottle was randomly selected from each group and digested with $0.2 \%$ trypsin. Cells were then harvested for smears and fixed for $20 \mathrm{~min}$ at $4^{\circ} \mathrm{C}$ with acetone, then washed with $1 \mathrm{X}$ PBS three times for 5 min each and air-dried. Bcl-2 and Bax immunohistochemistry was performed according to instructions supplied in the PV-9000 kits. Bcl-2- and Bax-positive cells displayed yellow or brown cytoplasmic staining. Staining was analyzed with automatic image analysis software using identical capture conditions for each field. Five fields (10x40) were randomly selected for analysis of the average optical density (AOD) of 50 cells to determine staining intensity of Bcl-2 and Bax proteins.

Statistical methods. SPSS13.0 software was used for data analysis. MTT and flow cytometry results were analyzed by single factor analysis of variance and SNK method; comparisons of $\mathrm{Bcl}-2$ and Bax protein expression were analyzed with independent samples t-test. Tests were 2-sided, with $\alpha$ level of 0.05 , and $\mathrm{P}<0.05$ was considered to denote statistical significance.

\section{Results}

Quercetin inhibits MCF-7 cell proliferation. Using MTT colorimetry to measure cell proliferation, we observed that 12.5 
Table I. Effects of quercetin on proliferation of MCF-7 human breast cancer cells.

\begin{tabular}{|c|c|c|c|c|c|c|c|c|}
\hline \multirow[b]{2}{*}{ Group } & \multirow[b]{2}{*}{ Dose $(\mu \mathrm{mol} / \mathrm{l})$} & \multirow[b]{2}{*}{$\mathrm{n}$} & \multicolumn{2}{|c|}{$24 \mathrm{~h}$} & \multicolumn{2}{|c|}{$48 \mathrm{~h}$} & \multicolumn{2}{|c|}{$72 \mathrm{~h}$} \\
\hline & & & A490 & $\operatorname{IR}(\%)$ & A490 & $\operatorname{IR}(\%)$ & A490 & IR $(\%)$ \\
\hline Control & - & 3 & $0.570 \pm 0.032$ & - & $0.718 \pm 0.028$ & - & $0.818 \pm 0.031$ & - \\
\hline \multirow[t]{7}{*}{ Quercetin } & 12.5 & 3 & $0.505 \pm 0.018^{\mathrm{a}}$ & 11.4 & $0.634 \pm 0.016^{\mathrm{a}}$ & 11.6 & $0.686 \pm 0.026^{\mathrm{a}}$ & 16.1 \\
\hline & 25 & 3 & $0.457 \pm 0.036^{\mathrm{a}}$ & 20.0 & $0.532 \pm 0.039^{\mathrm{a}}$ & 26.0 & $0.620 \pm 0.012^{\mathrm{a}}$ & 24.2 \\
\hline & 50 & 3 & $0.388 \pm 0.016^{\mathrm{a}}$ & 32.0 & $0.404 \pm 0.033^{\mathrm{a}}$ & 43.8 & $0.405 \pm 0.025^{\mathrm{a}}$ & 50.4 \\
\hline & 100 & 3 & $0.262 \pm 0.025^{\mathrm{a}}$ & 54.0 & $0.255 \pm 0.039^{\mathrm{a}}$ & 64.6 & $0.225 \pm 0.020^{\mathrm{a}}$ & 72.5 \\
\hline & 200 & 3 & $0.164 \pm 0.022^{\mathrm{a}}$ & 71.4 & $0.140 \pm 0.021^{\mathrm{a}}$ & 80.5 & $0.124 \pm 0.019^{\mathrm{a}}$ & 84.8 \\
\hline & $\mathrm{F}$ & - & 108.479 & - & 158.828 & - & 457.232 & - \\
\hline & P-value & - & 0.001 & - & 0.001 & - & 0.001 & - \\
\hline
\end{tabular}

IR, inhibition rate. ${ }^{\mathrm{a}} \mathrm{P}<0.05$ vs. control group.

Table II. Effects of quercetin on the cell cycle and apoptosis rate of MCF-7 human breast cancer cells.

\begin{tabular}{|c|c|c|c|c|c|}
\hline \multirow[b]{2}{*}{ Group } & \multirow[b]{2}{*}{ Dose $(\mu \mathrm{mol} / \mathrm{l})$} & \multicolumn{3}{|c|}{ Cell cycle } & \multirow[b]{2}{*}{ Apoptosis rate } \\
\hline & & $\mathrm{G}_{0} / \mathrm{G}_{1}$ & $\mathrm{~S}$ & $\mathrm{G}_{2} / \mathrm{M}$ & \\
\hline Control & - & $62.41 \pm 1.94$ & $26.74 \pm 2.75$ & $10.85 \pm 0.82$ & $0.42 \pm 0.04$ \\
\hline \multirow[t]{7}{*}{ Quercetin } & 12.5 & $59.92 \pm 1.94$ & $27.61 \pm 2.76$ & $12.47 \pm 0.91$ & $0.68 \pm 0.07$ \\
\hline & 25 & $51.43 \pm 1.56^{\mathrm{a}}$ & $31.68 \pm 2.38$ & $16.89 \pm 0.83$ & $1.26 \pm 0.09$ \\
\hline & 50 & $42.04 \pm 1.74^{\mathrm{a}}$ & $32.74 \pm 3.07$ & $25.23 \pm 1.36^{\mathrm{a}}$ & $8.53 \pm 0.55^{\mathrm{a}}$ \\
\hline & 100 & $30.70 \pm 1.93^{\mathrm{a}}$ & $37.47 \pm 2.81^{\mathrm{a}}$ & $31.83 \pm 0.89^{\mathrm{a}}$ & $11.54 \pm 0.75^{\mathrm{a}}$ \\
\hline & 200 & $29.74 \pm 1.24^{\mathrm{a}}$ & $58.00 \pm 1.94^{\mathrm{a}}$ & $12.26 \pm 0.73^{\mathrm{a}}$ & $23.15 \pm 1.91^{\mathrm{a}}$ \\
\hline & $\mathrm{F}$ & 199.022 & 57.618 & 241.377 & 316.291 \\
\hline & $\mathrm{P}$-value & 0.001 & 0.001 & 0.001 & 0.001 \\
\hline
\end{tabular}

${ }^{\mathrm{a}} \mathrm{P}<0.05$ vs. control group. Values are expressed as percentages.

Table III. Levels of Bcl-2 and Bax in MCF-7 cells.

\begin{tabular}{lccc}
\hline Group & $\mathrm{n}$ & $\mathrm{Bcl}-2$ & $\mathrm{Bax}$ \\
\hline Control group & 50 & $0.372 \pm 0.160$ & $0.251 \pm 0.092$ \\
Test group & 50 & $0.260 \pm 0.100$ & $0.336 \pm 0.127$ \\
$\mathrm{t}$ & & 4.226 & 3.828 \\
P-value & & 0.001 & 0.001 \\
\hline
\end{tabular}

Values for average optical density (AOD) are expressed as the mean $\pm \mathrm{SD}$.

and $25 \mu \mathrm{M}$ doses of quercetin did not inhibit proliferation of human breast cancer MCF-7 cells; however, higher doses (50, 100 and $200 \mu \mathrm{M}$ ) significantly inhibited proliferation of these cells (Fig. 1). Furthermore, inhibition of proliferation displayed both dose- and time-dependent relationships with quercetin treatment. At a quercetin concentration of $50 \mu \mathrm{M}$, the inhibition rate ranged between 32.0 and $50.4 \%$; at a concentration of $100 \mu \mathrm{M}$, the inhibition rate fell between 54.0 and $72.5 \%$; and when quercetin concentration was $200 \mu \mathrm{M}$, the inhibition rate ranged between 71.4 and $84.8 \%$. Compared with control samples, these differences in proliferation were statistically significant $(\mathrm{P}<0.05$; Table I).

Quercetin induces MCF-7 cell apoptosis. Using flow cytometry and comparing with untreated MCF-7 cells, the cell cycles of quercetin-treated MCF-7 cells were skewed (Table II). Specifically, the proportions of $\mathrm{G}_{0} / \mathrm{G}_{1}$ phase cells decreased significantly with all concentrations of quercetin $(\mathrm{P}<0.05)$. In contrast, the proportions of $\mathrm{S}$ phase cells increased significantly with quercetin concentrations of 100 and $200 \mu \mathrm{M}(\mathrm{P}<0.05)$, and the proportions of $\mathrm{G}_{2} / \mathrm{M}$ phase cells increased significantly with quercetin concentrations of 50, 100 and $200 \mu \mathrm{M}(\mathrm{P}<0.05)$. Additionally, PI staining enabled quantification of apoptosis. Apoptosis rates increased with increasing concentrations of quercetin; the apoptosis rates of MCF-7 cells treated with 50, 100 and $200 \mu \mathrm{M}$ quercetin were all significantly higher than those of the control MCF-7 cells $(\mathrm{P}<0.05)$. 
Bcl-2 and Bax protein expression. To further confirm increased rates of apoptosis in quercetin-treated MCF-7 cells, we assessed Bcl-2 and Bax protein expression by immunohistochemistry (Table III). Bcl-2 protein expression was significantly lower in quercetin-treated cells than in control cells $(\mathrm{t}=4.226, \mathrm{P}=0.001)$, while Bax protein expression was significantly higher following quercetin treatment $(\mathrm{t}=3.828, \mathrm{P}=0.001)$.

\section{Discussion}

Previous in vivo and in vitro experiments demonstrated that quercetin inhibits the growth of breast, ovarian, colon, liver and stomach cancers as well as leukemia and other malignant tumors, likely by blocking cell cycles, inhibiting tumor cell signaling, and regulating growth factors to prevent further cell proliferation and to induce tumor cell apoptosis (11). Our study of the effects of quercetin on MCF-7 breast cancer cells demonstrates its ability to inhibit proliferation of these cells in a dose- and time-dependent manner.

Proliferation of tumor cells depends on completed cell cycles (12), which are regulated and controlled by the $\mathrm{G}_{1} / \mathrm{S}$ and $\mathrm{G}_{2} / \mathrm{M}$ checkpoints. These checkpoints trigger mitotic spindle assembly and ensure that downstream activities are initiated when upstream activities are properly completed (13). Cell cycle checkpoint regulation also removes damaged cells by inducing apoptosis and blocking cell cycle progression (causing apoptosis); indeed, apoptosis is often accompanied by cellgrowth retardation (14). Using flow cytometry we showed that, after treatment of human breast cancer cells with quercetin for $72 \mathrm{~h}$, the proportion of cells in the $\mathrm{G}_{0} / \mathrm{G}_{1}$ phase decreased, while the proportion of cells in $\mathrm{S}$ phase increased, suggesting that quercetin blocked transition from $S$ phase to $G_{2} / M$ phase. Notably, the proportion of cells in $\mathrm{G}_{2} / \mathrm{M}$ phase also increased, indicating cell cycle retardation at this checkpoint; however, at a quercetin concentration of $200 \mu \mathrm{M}$, the proportion of cells in $G_{2} / M$ phase decreased. The reason for this change remains unclear. However, we used PI staining to verify that more cells underwent apoptosis following treatment with quercetin, and that rates of apoptosis increased as quercetin dose increased.

$\mathrm{Bcl}$-2, or B-cell lymphoma/leukemia-2, is a proto-oncogene that inhibits apoptosis through antioxidant activity and inhibition of transmembrane flow of calcium ions. Bax is a related gene with the ability to antagonize $\mathrm{Bcl}-2$ protein and promote apoptosis (15). Bax protein expression is closely related to development of various malignant tumors and is significantly reduced in some of them $(16,17)$. In this study, immunohistochemistry for Bcl-2 and Bax following treatment of MCF-7 cells with $200 \mu \mathrm{M}$ of quercetin indicated that cells showed decreased expression of $\mathrm{Bcl}-2$ but increased expression of Bax. This finding demonstrates that reduced expression of an antiapoptotic protein and increased expression of a pro-apoptotic protein resulted in higher rates of apoptosis following quercetin treatment.

In conclusion, quercetin treatment decreases proliferation and increases apoptosis in MCF-7 human breast cancer cells. Apoptosis is induced via upregulation of Bax protein and downregulation of Bcl-2 protein. The mechanisms by which quercetin regulates $\mathrm{Bcl}-2$ and $\mathrm{Bax}$ expression require further study, but this compound shows promise as a potential chemotherapeutic.

\section{Acknowledgements}

This study was supported by a grant from the Natural Science Foundation of Tianjin City (08JCYBJC05500).

\section{References}

1. Chow LW and Loo WT: The differential effects of cyclophosphamide, epirubicin and 5-fluorouracil on apoptotic marker (CPP-32), pro-apoptotic protein (p21 (WAF-1)) and anti-apoptotic protein (bcl-2) in breast cancer cells. Breast Cancer Res Treat 80: 239-244, 2003.

2. Jemal A, Siegel R, Xu J and Ward E: Cancer statistics, 2010. CA Cancer J Clin 60: 277-300, 2010

3. Jemal A, Bray F, Center MM, Ferlay J, Ward E and Forman D: Global cancer statistics. CA Cancer J Clin 61: 69-90, 2011.

4. Yang L, Parkin DM, Ferlay J, Li L and Chen Y: Estimates of cancer incidence in China for 2000 and projections for 2005. Cancer Epidemiol Biomarkers Prev 14: 243-250, 2005.

5. Normanno N, Morabito A, De Luca A, et al: Target-based therapies in breast cancer: current status and future perspectives. Endocr Relat Cancer 16: 675-702, 2009.

6. Early Breast Cancer Trialists' Collaborative Group (EBCTCG): Effects of chemotherapy and hormonal therapy for early breast cancer on recurrence and 15-year survival: an overview of the randomised trials. Lancet 365: 1687-1717, 2005.

7. Hollman PC and Katan MB: Dietary flavonoids: intake, health effects and bioavailability. Food Chem Toxicol 37: 937-942, 1999.

8. Kim WK, Bang MH, Kim ES, et al: Quercetin decreases the expression of ErbB2 and ErbB3 proteins in HT-29 human colon cancer cells. J Nutr Biochem 16: 155-162, 2005.

9. Yang JH, Hsia TC, Kuo HM, et al: Inhibition of lung cancer cell growth by quercetin glucuronides via $\mathrm{G}_{2} / \mathrm{M}$ arrest and induction of apoptosis. Drug Metab Dispos 34: 296-304, 2006.

10. Van Meeuwen JA, Ter Burg W, Piersma AH, van den Berg M and Sanderson JT: Mixture effects of estrogenic compounds on proliferation and pS2 expression of MCF-7 human breast cancer cells. Food Chem Toxicol 45: 2319-2330, 2007.

11. Ackland ML, van de Waarsenburg S and Jones R: Synergistic antiproliferative action of the flavonols quercetin and kaempferol in cultured human cancer cell lines. In Vivo 19: 69-76, 2005.

12. Hartwell LH and Kastan MB: Cell cycle control and cancer. Science 266: 1821-1828, 1994.

13. Hartwell LH and Weinert TA: Checkpoints: controls that ensure the order of cell cycle events. Science 246: 629-634, 1998.

14. Chiarugi V, Magnelli L, Cinelli M and Bai G: Apoptosis and the cell cycle. Cell Mol Biol Res 40: 603-612, 1994.

15. Korsmeyer SJ, Shutter JR, Veis DJ, Merry DE and Oltvai ZN: Bcl-2/Bax: a rheostat that regulates an anti-oxidant pathway and cell death. Semin Cancer Biol 4: 327-332, 1993.

16. Cvejic D, Selemetjev S, Savin S, Paunovic I, Petrovic I and Tatic S: Apoptosis and proliferation-related molecules (Bcl-2, Bax, p53, PCNA) in papillary microcarcinoma versus papillary carcinoma of the thyroid. Pathology 40: 475-480, 2008.

17. Nehls O, Okech T, Hsieh CJ, et al: Studies on p53, BAX and $\mathrm{Bcl}-2$ protein expression and microsatellite instability in stage III (UICC) colon cancer treated by adjuvant chemotherapy: major prognostic impact of proapoptotic BAX. Br J Cancer 96: 1409-1418, 2007. 